\section{EREM 75/3}

Journal of Environmental Research, Engineering and Management Vol. 75 / No. 3 / 2019 pp. $33-45$

DOI 10.5755/j01.erem.75.3.23323
Environmental Impact of Devastated Landscapes of Volhynian Upland and Male Polisya (Ukraine)

Received 2019/05

Accepted after revision 2019/11

\title{
Environmental Impact of Devastated Landscapes of Volhynian Upland and Male Polisya (Ukraine)
}

\section{V. Popovych*}

Lviv State University of Life Safety, 35 Kleparivska str. Lviv, 79000, Ukraine

\author{
A. I. Voloshchyshyn \\ Lviv State University of Life Safety, 35 Kleparivska str. Lviv, 79000, Ukraine
}

*Corresponding author: popovych2007@ukr.net

Lviv-Volyn coal basin located on the territory of Ukraine within the Volhynian Upland and Male Polisya is one of the largest in Europe. The purpose of our research is to highlight the environmental impact of the devastated landscapes of coal mines. Samples of edaphotopes were collected in accordance with existing state standards and approved techniques. It has been found that the ash content of operating and non-operating dumps is different. The average content of ash in the rock of non-operating dumps is $79.95 \%$, and in particles of a diameter of up to $13 \mathrm{~mm}$, it is $78.22 \%$. In operating dumps, the ash content of coal-containing particles is the lowest and ranges within 12.5-25.6\% (average value 20.08\%). The average ash content in operating dumps with rock particle size of $1-13 \mathrm{~mm}$ is $86.45 \%$. The average ash content in operating dumps with particle size up to $1 \mathrm{~mm}$ is $72.25 \%$. Coal-containing rock and rock with a particle size of up to $1 \mathrm{~mm}$ are most liable for spontaneous fire. The average sulphur content in the rock of non-operating dumps is $0.94 \%$. The average sulphur content in operating dumps with coal-containing particles of $1-13 \mathrm{~mm}$ is $1.86 \%$. Coal-containing particles are the most dangerous from the point of view of the sulphur content, which interacts with other components and chemical elements and migrates to the environment. In order to overcome the environmental impact of waste heaps of coal mines, green technologies should be implemented to non-operating dumps. Such technologies include biological reclamation, including forest and agricultural vegetative reclamation, and monitoring of the environment in mines area. It is necessary to introduce modern technological processes, the latest transportation and techniques, as well as control of warehouse technologies, at the operating dumps.

Keywords: environmental impact, devastated landscape, waste heap, Volhynian Upland, Male Polisya. 


\section{Introduction}

Lviv-Volyn coal basin located on the territory of Ukraine within the Volhynian Upland and Male Polisya is one of the largest in Europe. It smoothly moves into the territory of Poland and is called Lublin coal basin. In Poland the Lviv-Volyn coal basin is considered to be the eastern part of Lublin coal basin. This coal basin is located in the northwest of Ukraine in the upper river of the Western Bug. The area of the basin is $1,400 \mathrm{~km}^{2}$, the length is $190 \mathrm{~km}$, and the average width is $60 \mathrm{~km}$. The Lviv-Volyn coal basin consists of 3 mining regions, only two of which, i.e., Novovolynsk and Chervonohrad, are operated. Novovolynsk mining area is located in the north of the basin within the Volhynian Upland, and Chervonohrad is located in the south within the area of Male Polisya (Fig. 1).

Fig. 1. Plan of Lviv-Volyn coal basin and its mining areas (according to Mykhaylov, 2009)

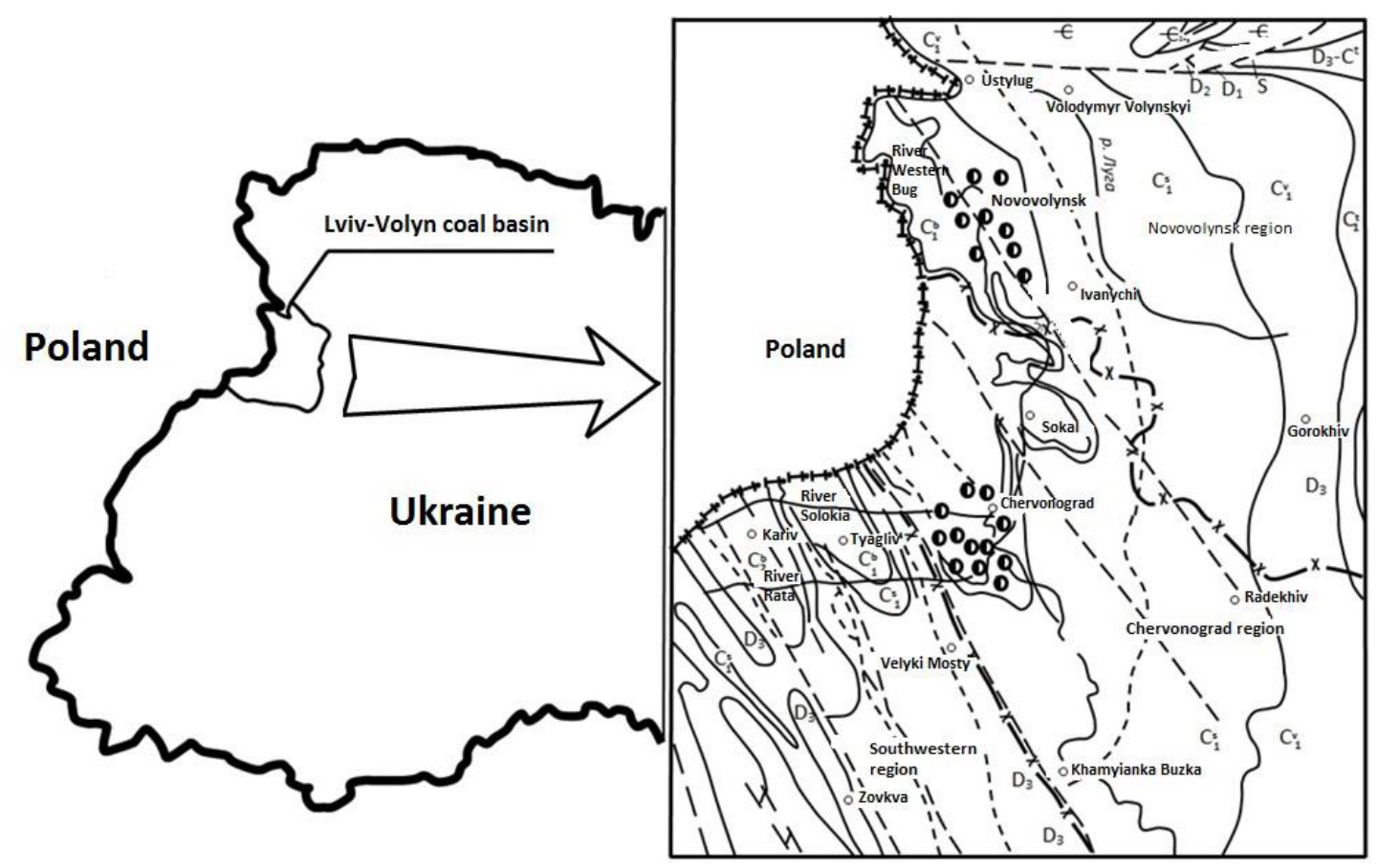

Mining industry is one of the most important components of the economic potential of the Volyn and Lviv regions of Ukraine. The general state of the industry significantly influences socio-economic development and its main indicators, such as employment, budgeting, etc. After the closure of non-profitable mines in the territory of the Lviv-Volyn coal basin, raising the groundwater level is observed being a result of mine flooding. Underground waters underlay the groundwater at $20-40 \%$ of the mine drainage. The process is progressive. Intensive flooding is typical of the areas near the operating mines. Most affected by the flooding are Novovolynsk city, the village of Blagodatne, the village of Budyatich, Ivanychivsky district of the Volyn region, and the village of Hirnyk of the Lviv region. Mine closure has contributed to the improvement of the ecological situation in the region. At the same time, the total inflow of pollutants, namely heavy metals into the environment, remains at the same level. It is caused by the soil ability to accumulate pollutants and as a result be a secondary source of pollution for a long time (Popovych, 2018). At the 
same time, waste heaps of coal mines are still a powerful landscape-transforming factor of ecological risk (Fig. 2).

Fig. 2. Waste heap of Velykomostivska mine (photo made by Popovych V. V.)

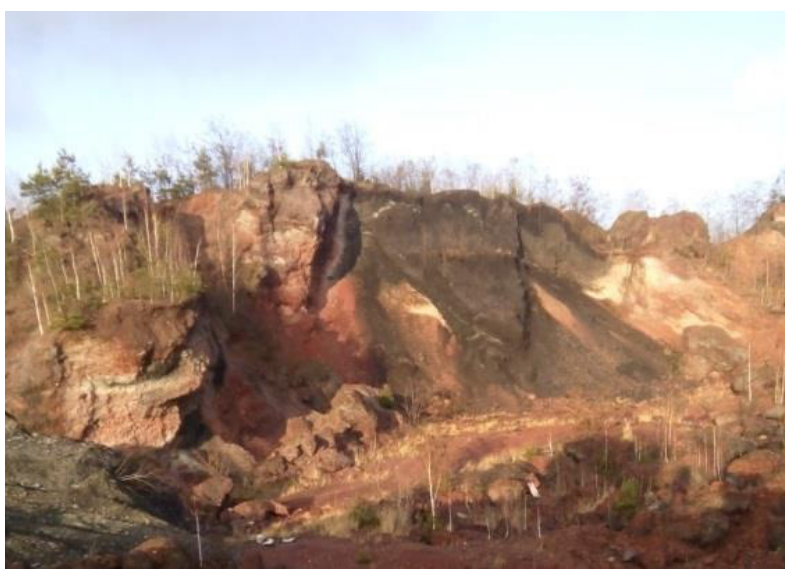

There are 24 and 31 dumps of coal mines within the Novovolynsk and Chevonorgrad mining areas, respectively (Haydin, 2018). These devastated landscapes have a negative effect on the ecological state of Novovolynsk and Chervonograd and their suburbs. There are four mines on the territory of the Novovolynsk mining area: Buzhanska mine, mine №1 Novovolynska, mine №5 Novovolynska, and mine №9 Novovolynska. After the closure of non-profit mines on the territory of the Novovolynsk mining area (from 1996 until 2001 six non-profitable mines were shut down), karsts began to be appear (Ekolohichnyy passport, 2018). Generally, in the Novovolynsk mining area, 31999.5 tons of rock are found in dumps.

Since the Chervonograd mining area is represented by more quantity of operating mines and devastated landscaped, we will focus more on this area. As a result of waste heaps, burning hazardous substances and compounds come into the air, ground water and soil. In the zone of mine exploitation, the radiation background is higher (Pavlichenko, 2016; Karabyn, 2018).

In the investigated region, operating (which are still dumped) and non-operating dumps (the dumping is stopped and self-growing is caused by vegetation) are located. In general, 17,994,749 $\mathrm{m}^{3}$ of rock was accumulated in the dumps of the investigated mines (including burnt ones and those that are still burning). An important environmental challenge is the restoration of the vegetation of devastated landscapes through reclamation works (Klimkina, 2018). It should be noted that on the waste heaps the vegetation is restoring by representatives of the zonal flora (Bashutska, 2016). This gives an opportunity to predict successional processes during optimization of ecosystems of the devastated landscapes.

\section{Methods}

The purpose of our research is to report the environmental hazards of the devastated landscapes of coal mines operating within the Volhynian Upland and Male Polisya of Ukraine, as well as to investigate the influence of the natural climatic, geographic, soil and geo-botanical conditions of their operation.

According to the purpose of the work, the following tasks were assigned:

to determine the natural climatic and other conditions that cause the formation of devastated landscapes of coal mines;

to find out the volume of waste rock on certain dumps and mines in general;

to determine the factors of devastated landscapes of coal mines influencing the environment;

to determine the ash and sulphur content in the waste rock and its bulk density;

to propose the main environmental measures within the devastated landscapes.

Geographical environment. The Volhynian Upland occupies the southern part of the Volyn and Rivne regions, the Sokalsky district of the Lviv region and a small northern part of the Khmelnytsky region. The western border of the area passes along the Western Bug, the northern border is on the line of Ustylug Lutsk - Rivne - Korets, the eastern is on the line Korets - Staryi Kryvyn, and the southern is from Chervonograd through Ostrog and then to the Staryi Kryvyn.

Male Polisya is located between the Volhynian Upland on the north side and the Podilsk forest-steppe upland on the south. Male Polisya stretches from the cities of Shepetivka and Slavuta on the east to the Khmelnytsky region, on the west up to Rava-Ruska, Lviv region, and smoothly moves to the territory of Poland. 
Climatological conditions. The climate of the Volhynian Upland is moderate continental, close to the climate of Western and Male Polisya. The average annual temperature is $+7.4^{\circ} \mathrm{C}$; the minimum temperatures are around $-34^{\circ} \mathrm{C}$, the maximum reaches $+36^{\circ} \mathrm{C}$. Rainfall reaches from $560 \mathrm{~mm}$ in Ostrog to $630 \mathrm{~mm}$ in Volodymyr-Volynsky a year. Arid years with rainfall of $350 \mathrm{~mm}$ are rare - once in 15-20 years.

Male Polisya is influenced by the air masses coming from the Atlantic Ocean and the south-western part of Europe. Such a geographical situation has contributed to the formation of oceanic continental climate, characterized by unstable weather conditions, high relative humidity, and a significant amount of rainfall. The heat resources of the area are sufficient for the cultivation of many crops, because the growing season lasts for more than 200 days. Period with active temperatures (more than $+10^{\circ} \mathrm{C}$ ) lasts for $150-160$ days. More than 100 days a year have a daily average temperature of more than $+15^{\circ} \mathrm{C}$ (period of intense vegetation). Prolonged thaws cause long winters.

Soil conditions. The soils of Volhynian Upland are more fertile than in the West Polisya region. Under the woods, light gray and dark gray forest soils on forest loams dominate. Podzolic chernozems and dark gray forest soils are mostly cultivated and used for agricultural production. In a small area under pine forests, sod-podzolic soils are located; in valleys and rivers occupied by alder forests, there are meadow soils and lowland peatlands. In general, the soil-climatic conditions are favourable for the cultivation of valuable species - oak, walnut, ash and others.

In the region of Male Polisya, sod-podzolic, meadow and marsh soils predominate. The most common are soddy and lightly podzolic soils, which occupy the gentle and low poorly drained interstream areas. Sod-weak podzolic sandy soils are depleted. They contain 0.6$1.3 \%$ of humus, poorly provided with labile soil nutrients (nitrogen - 1.1-6.5, phosphorus $0.4-5.5$, potassium $0.3-4.5 \mathrm{mg}$ per $100 \mathrm{~g}$ of soil). The $\mathrm{pH}$ of the soil solution is slightly acidic $(\mathrm{pH}=4.7-5.4)$. The total absorbed bases are 1.0-2.6 mg-eq per $100 \mathrm{~g}$ soil, the degree of saturation with the bases is $22.1-38.5 \%$. Hydrolytic acidity is low and is up to $1.5-3.3 \mathrm{mg}$-eq per $100 \mathrm{~g}$ of soil, which is associated with a very small sorptive capacity [8].
Geobotanical conditions. Forests of the Volhynian Upland area are low - 15.3\%. Forest vegetation is quite diverse. Oak (37\%) and pine (36\%) stands dominate including the mixed pine-oak and oak-pine plantations. In the oak forests, there is an English oak, less often a durmast oak, which grows usually in higher places with the limestone exposure. Sufficiently large areas are occupied by hornbeam, birch and aspen trees (14\%), which have arisen as a result of changes in rocks in oak and pine-oak forests. In the river valleys, there is black alder (8\%). Considerable place is occupied by Scotch pine, English oak with an admixture of birch, lime, maple, hornbeam, etc.

In the Male Polisya area, hornbeams in pine woods and hazel together with oak have a positive effect on the decomposition of litter and, thus, accelerate the biocourse of substances and facilitate the mobilization of potential resources of nutrients to meet the needs of wood species. Hornbeam-oak-pine stands are found mainly in fresh, moist and damp complex subors, within which there are several indigenous associations. Oak-pine forests (Querceto-Pineta) comprise the second genesis level of pine forests, which are formed on more fertile soils of subors (sod, low and medium podzolic sandy and sandy-loam). The third evolution level of pine forests is hornbeamoak-pine phytocoenosis (Carpineto-Querceto-Pineta). They grow on even more fertile soils of complex subors (Gonchar, 1983).

Hydrogeological conditions. The investigated territory is part of the Volyn-Podilsky Artesian basin in its north-western part. The following aquifers are presented here: quaternary deposits, crumbling marls of the Senonian stage of the Cretaceous system, Jurassic sandstones, Vise and Namurian stages, and Devonian limestones (Haydin, 2018).

For investigation of ecological hazards of devastated landscapes, samples of edaphotopes were collected in accordance with existing state standards and approved methods (DSTU 4287:2004; DSTU ISO 10381-8l; DSTU ISO 18512; DSTU ISO 11464:2007; DSTU 4362:2004). Physicochemical studies of edaphotopes and soils within the horizons were carried out in accordance with the methodical guidelines by N. B. Myakina and Ye. V. Arynuskina (Myakina, 1979). 
The size distribution of the soil was determined by the Kachinsky method with application of the pyrophosphate preparation method. The software is a package of applications Surfer, MS Excel, MS Visio. Mathematical and statistical, ecological, pedological, geochemical methods of research, as well as correlation analysis were applied.

\section{Results and Discussion}

Ash content (the percentage of unburnt residue) is an important physicochemical indicator of the rock refuse. The average ash content of the existing dumps is $79.1-79.4 \%$. According to surveys, the highest ash content is in the operating dump of the "Lisova" mine and is $88.4 \%$. The lowest is in "Chervonogradska" mine (73.7\%) (Fig. 3).

It is common knowledge that sulphur in the various compounds in quantities is present in all solid fossil fuels, regardless of their nature and metamorphism.
In solid fuels, sulphur is presented by organic sulphur, which is part of the organic fuel mass; sulphur in sulphides $S_{S}$ and pyrite $S_{p}$, which includes sulphides and bisulfides of metals; sulphate, which is contained in the form of metal sulphates; and elemental sulphur, which is present in the rock in free state. The total sulphur $\mathrm{S}_{\mathrm{T}}$ is the sum of these varieties of sulphur. An indicator of technical analysis - total sulphur in coal $\left(\mathrm{S}_{T}, \%\right)$ - indicates the total sulphur content in all compounds, expressed as elemental sulphur (\%). In the rock of operating dumps, the average sulphur content is $0.94-1.13 \%$ and they are characterized as low sulphur. The highest sulphur content, according to surveys, was set for the dumps of the "Stepova" mine $(1.83 \%)$, and the lowest for "Vidrodzhennya" mine (0.3\%) (Fig. 4).

The packed density of operating waste heaps is, on average, $1.86 \mathrm{t} / \mathrm{m}^{3}$. The highest density of the rock is on the "Zarichna" mine $\left(2.29 \mathrm{t} / \mathrm{m}^{3}\right)$, the lowest is on the "Stepova" and "Mezhyrichanska" mines (1.62 t/m³) (Fig. 5).

Fig. 3. Average ash content of the operating dumps

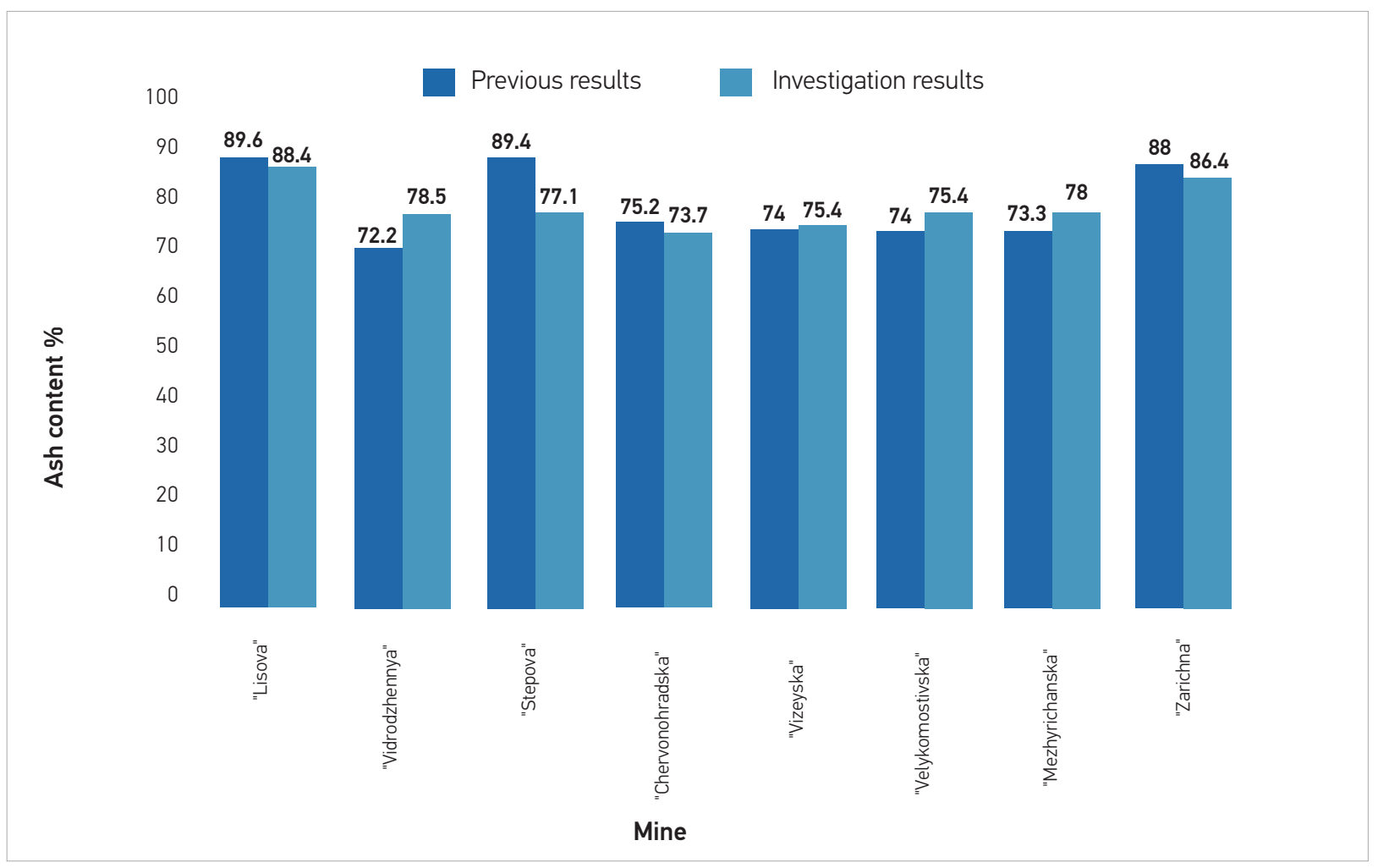


Fig. 4. Average sulphur content in the operating dumps

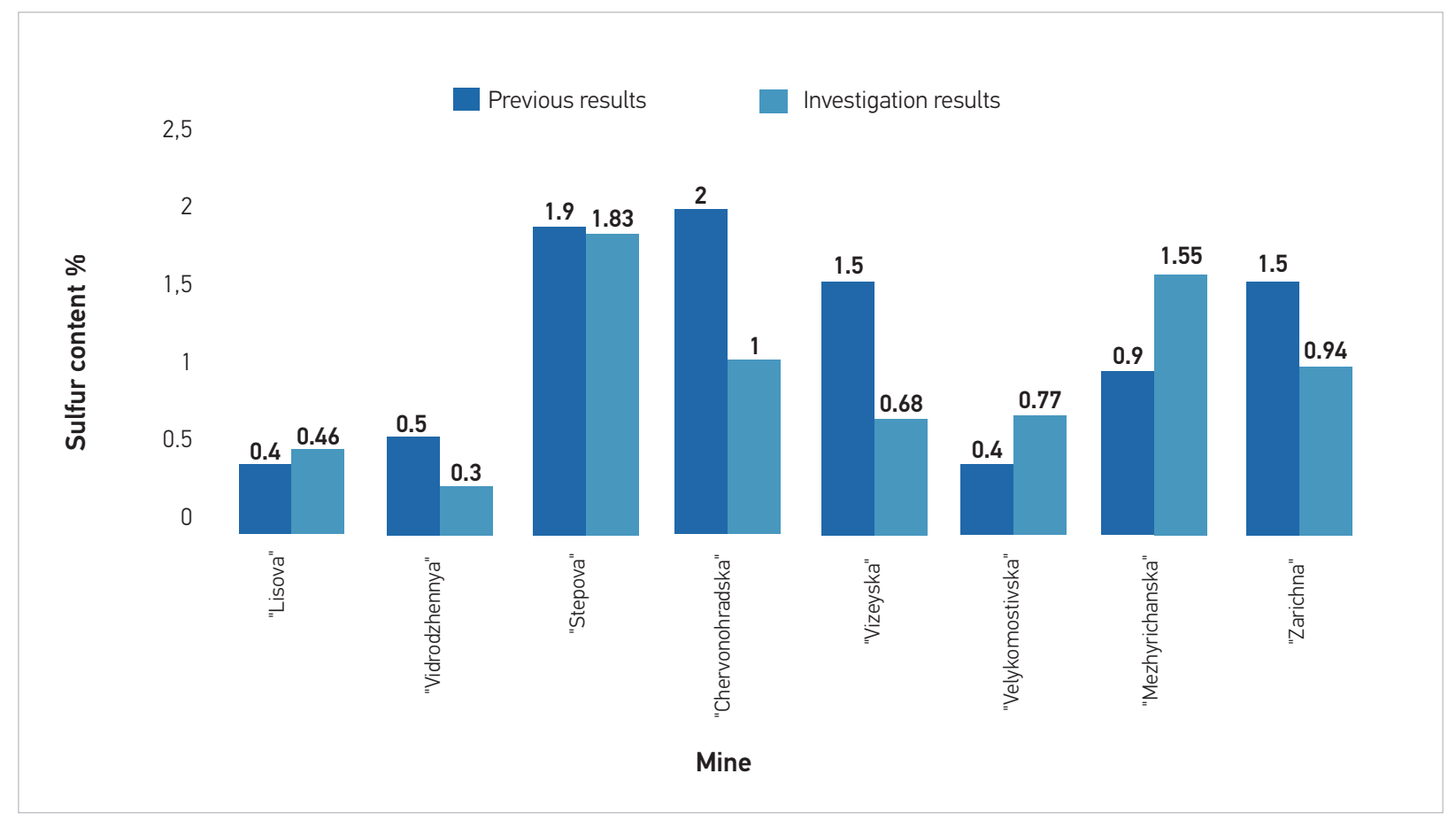

Fig. 5. Packed density of operating dumps, $t / \mathrm{m}^{3}$

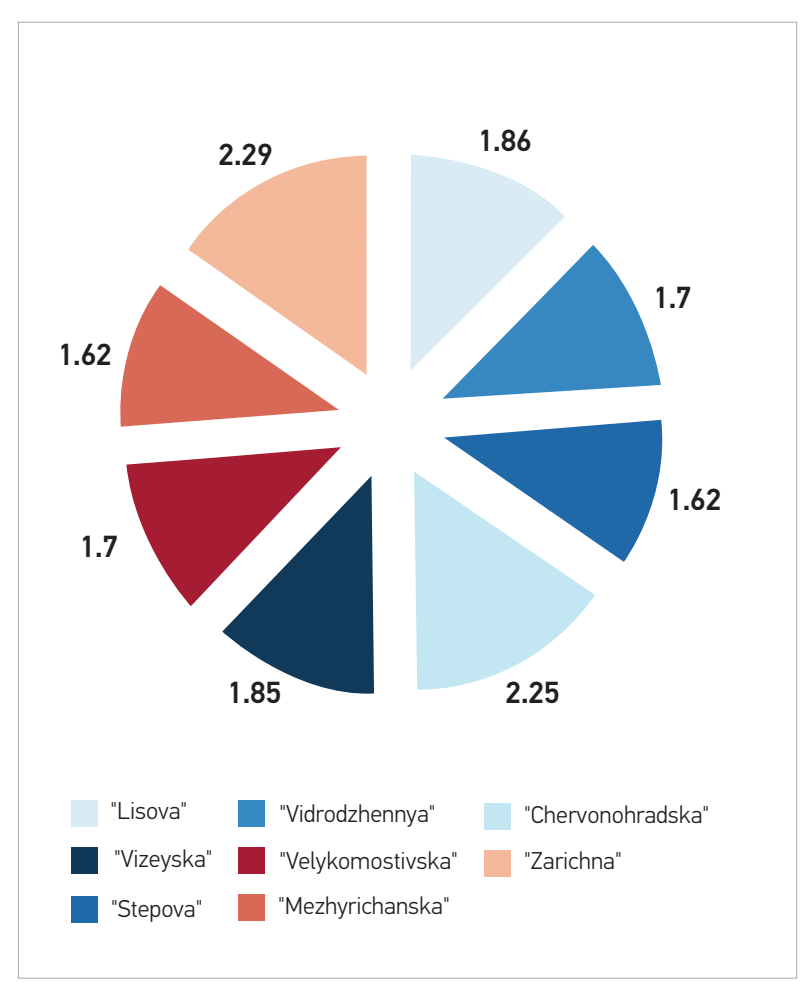

The packed density of the rocks in the range of 1.2-3.0 $\mathrm{t} / \mathrm{m}^{3}$ is much more dependant on porosity than other rocks, as well as on the density of the liquid and gas phases. The influence of these factors on sedimentary rocks of various origins differs: for detrital rocks, the particle size distribution, the way of grain combination and the nature of case hardening are crucial; for colloidogenic (sedimentary rocks formed by deposition and crystallization of colloids of any composition from natural colloids solutions), the diagenetic and epigenetic transformations, etc. are critical. The effect of the voids filler on the density is controlled by the value of the open porosity (Bezrodna, 2015).

Thus, the particle size distribution of the rock influences its packed density, which in turn affects the ash content and the content of sulphur. Let us consider the physical and chemical parameters of non-operating dumps with allowance for the particle size distribution. Such dumps are the places of increased ecological and man-made danger because on their surface the processes of spontaneous firing are observed. During spontaneous firing of dumps in coal mines, the decomposition of pyrite with the formation 
of $\mathrm{Fe}(\mathrm{OH})_{3}$ and elemental sulphur occurs.

Dumps and waste coal contain about $1 \%$ of pyrite. Their oxidation leads to the formation of sulphuric acid and ready soluble iron sulphates. As a result, sulphate wastewaters accumulate at the foot of the dumps and waste heaps. Oxidation of pyrite occurs by the following reaction: $2 \mathrm{FeS}_{2}+4 \mathrm{O}_{2}+2 \mathrm{H}_{2} \mathrm{O}=2 \mathrm{FeSO}_{4}+$ $2 \mathrm{H}_{2} \mathrm{SO}_{4}$. Iron sulphate (II) in the presence of free oxygen is converted into iron sulphate (III): $4 \mathrm{FeSO}_{4}+2$ $\mathrm{H}_{2} \mathrm{SO}_{4}+\mathrm{O}_{2}=2 \mathrm{Fe}_{2}\left(\mathrm{SO}_{4}\right)_{3}+2 \mathrm{H}_{2} \mathrm{O}$. Iron sulphate (III) is hydrolyzed to form iron hydroxides: $\mathrm{Fe}_{2}\left(\mathrm{SO}_{4}\right)_{3}+6 \mathrm{H}_{2} \mathrm{O}=$ $2 \mathrm{Fe}(\mathrm{OH})_{3}+3 \mathrm{H}_{2} \mathrm{SO}_{4}$. Insoluble iron hydroxides precipitate, forming limonite group minerals, which lead to a decrease of the permeability of the sand layer. The sulphuric acid is formed under the dumps. It penetrates into the underground horizons and is spread by ground waters (Malyk \& Holets, 2008).

Long-term discharges of crude water are accompanied by a decrease in self-purification capacity of the rivers, accumulation of dangerous compounds in the mud, and the formation of hazardous chemicals (Yadav \& Jamal, 2018; Tulaydan et al., 2017).

The average ash content in the rock of non-operating dumps is $79.95 \%$, and in particles with a diameter of up to $13 \mathrm{~mm}$, it is $78.22 \%$. From there we can conclude that the particles of the rock with a diameter of up to $13 \mathrm{~mm}$ are liable to spontaneous firing (Fig. 6).

The analysis of the sulphur content in the rock of non-operating dumps with different particle size distribution revealed that in particles of the rock with a diameter of up to $13 \mathrm{~mm}$ it was rather high (average value $1.06 \%$ ). In general, in the rock of non-operating dumps the average sulphur content is $0.94 \%$ (Fig. 7)

The content of particles with a diameter of up to 13 $\mathrm{mm}$ in the rock of non-operating dumps is an average of $45.36 \%$. However, in the waste heaps of the "Vizeyska", "Velykomostivska" and "Stepova" mines, the content of particles up to $13 \mathrm{~mm}$ is $65-76.8 \%$, which is much higher than in other coal mines. The lowest content of particles up to $13 \mathrm{~mm}$ is in the dump

Fig. 6. Average ash content in the rock of non-operating dumps

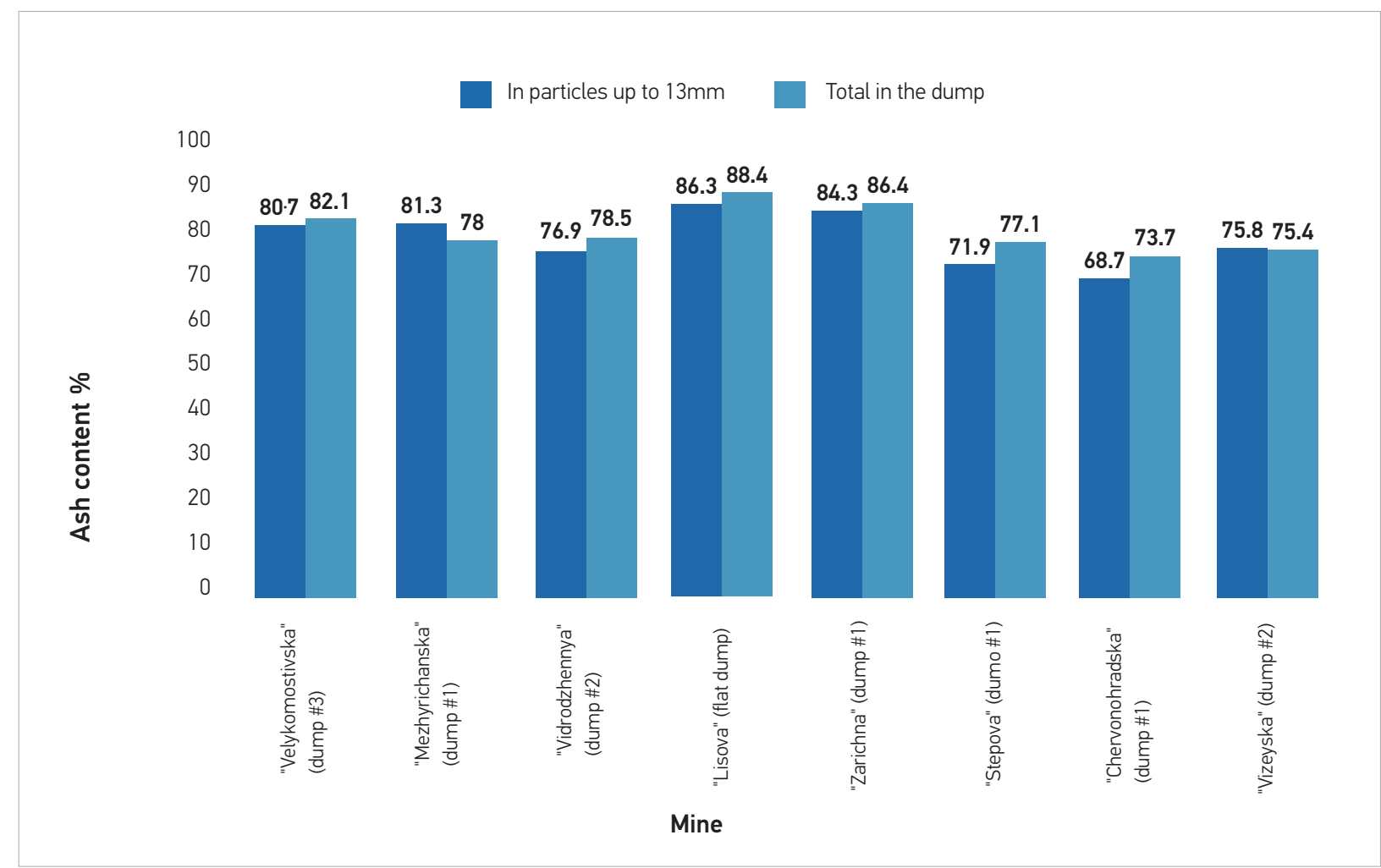


Fig. 7. Average sulphur content in the rocks of non-operating dumps

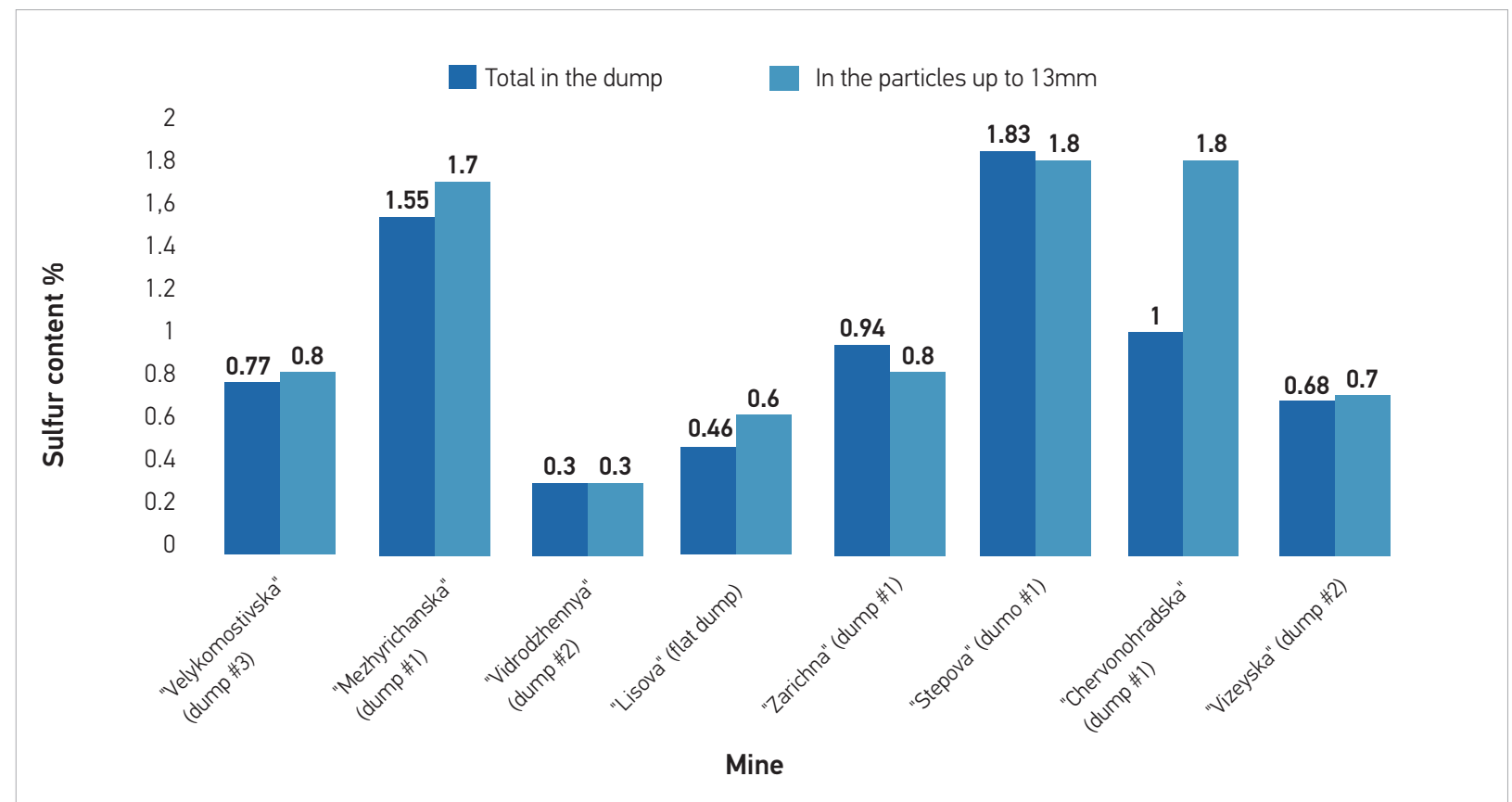

of the "Chervonohradska" mine (16.4\%) (Fig. 8).

Important indicators that influence the ability of the rock to spontaneous firing are the content of coal-containing and rock fractions. Moreover, it is necessary to distinguish between particles of rock fractions, depending on the particle size distribution. Uneven sizes of the rock particle influence the ecological safety of the environment in different ways (Yadav \& Jamal,

Fig. 8. The content of particles with a diameter of up to $13 \mathrm{~mm}$ in the dump rock

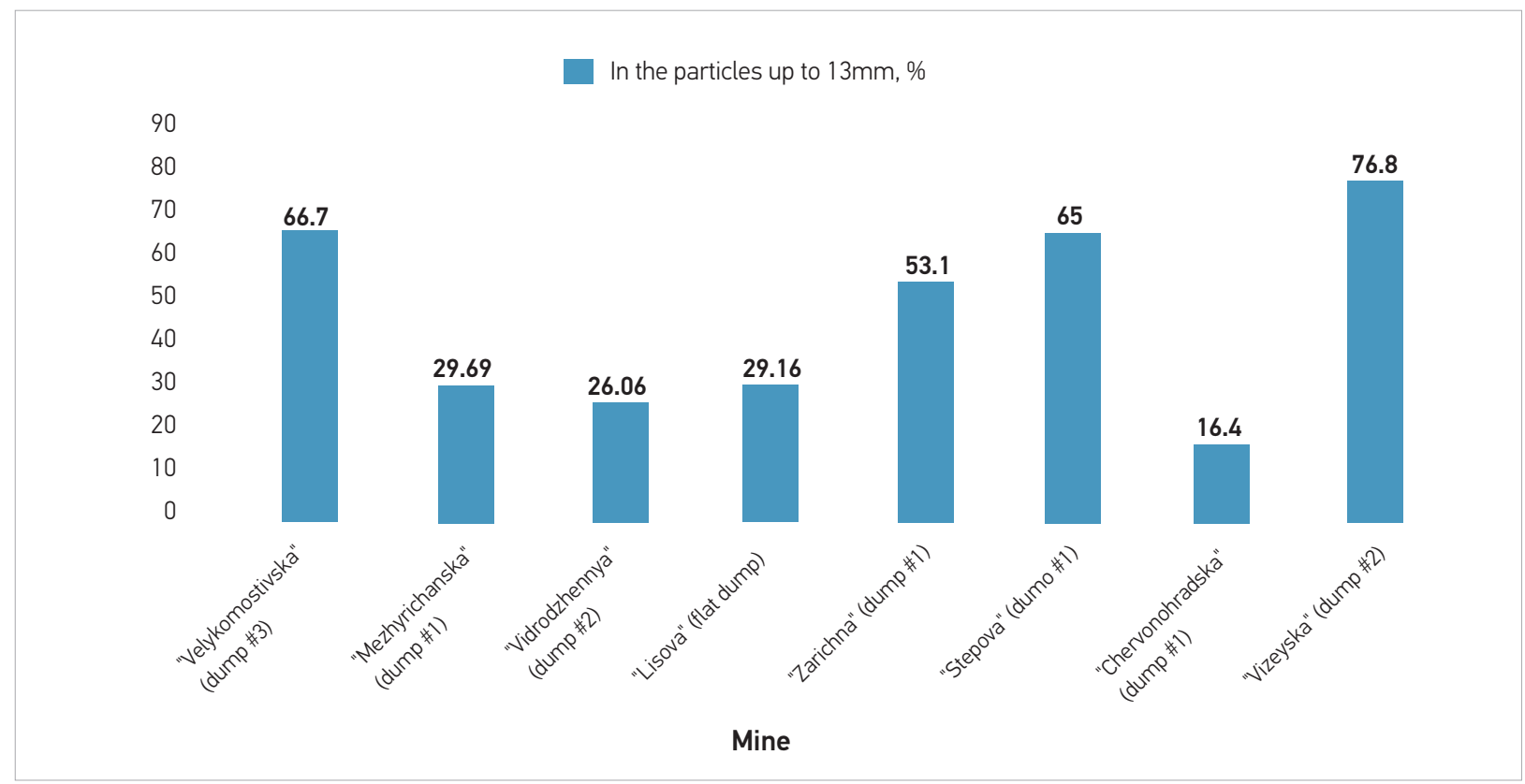


2016; Yadav, 2015; Klimkina, Kharytonov \& Zhukov, 2018; Chetveryk et al., 2018). The highest content of coal-containing fractions were found in the dumps of the "Vizeyska", "Chervonohradska" and "Stepova" mines (14.72\%, 16.74\%, and $16.9 \%$ respectively). The lowest content of coal-containing fractions were found in the dumps of "Zarichna" and "Lisova" mines (2.51\% and $2.52 \%)$. The average value for all dumps is $8.98 \%$, which is considered to be rather high.

In dumps, the part of rock with a density above 1,800 $\mathrm{kg} / \mathrm{m}^{3}$ with a particle size of $1-13 \mathrm{~mm}$ is $75.96 \%$ (average), and that with a particle size up to $1 \mathrm{~mm}$ is $15.05 \%$ (average). The highest content of the rock (with a particle size of 1-13 $\mathrm{mm}$ ) is concentrated in the dump of "Vidrodzhennya" mine (90.5\%), and the lowest is in the dump of the "Viseyska" mine (62.16\%). The highest content of the rock (with a particle size up to $1 \mathrm{~mm}$ ) is concentrated in the dump of the "Velykomostivska" mine (26.39\%), and the lowest is in the dump of "Vidrodzhennya" mine (5.9\%) (Fig. 9).

Fig. 9. The content of coal-containing and rock fractions in dumps

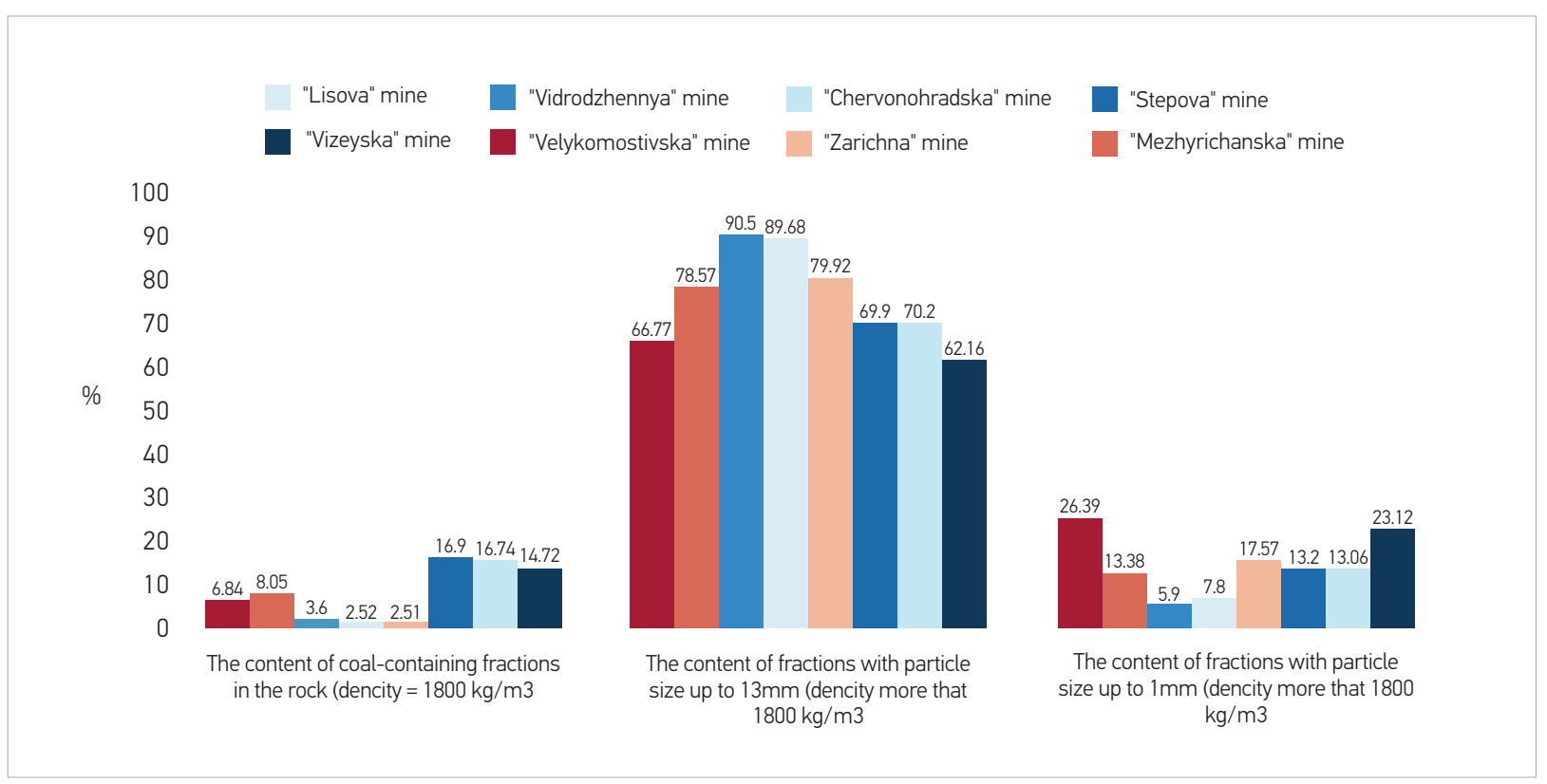

The coal-containing particles of the rock are in a robust relationship with the rock fractions with a diameter of $1-13 \mathrm{~mm}$ (the correlation coefficient is high, negative $K=-0.75745)$. However, the relationship between coal-containing rocks in dumps and rock fractions with a diameter of up to $1 \mathrm{~mm}$ is absent (the correlation coefficient is low $\mathrm{K}=0.23784$ ). The rock fractions are interdependent i.e. when the content of the rock with particle size of $1-13 \mathrm{~mm}$ increases, the content of the rock with a particle size of $1 \mathrm{~mm}$ in the dump decreases (the correlation coefficient is high, negative $K=-0.81431$ ) and vice versa (Table 1 ).

Table 1. Correlation index of coal-containing and rock fractions in the dumps

\begin{tabular}{l|c|c|c}
\hline Fractions content, $\%$ & Coal-containing fractions, $\%$ & Rock fractions $(\mathrm{d}=1-13 \mathrm{~mm}), \%$ & Rock fractions $(\mathrm{d} \leq 1 \mathrm{~mm}), \%$ \\
\hline Coal-containing fractions, $\%$ & 1 & & \\
\hline Rock fractions $(\mathrm{d}=1-13 \mathrm{~mm}), \%$ & -0.75745 & 1 & -0.81431 \\
\hline Rock fractions $(\mathrm{d} \leq 1 \mathrm{~mm}), \%$ & 0.23784 & 1 \\
\hline
\end{tabular}


The ash content of coal-containing particles of the dump rock is the lowest and is in the range of 12.525.6\% (average value 20.08\%). The highest ash content of coal-containing fractions of the rock is observed for the "Vidrodzhennya" mine (25.6\%), and the lowest one is for the "Stepova" mine (12.5\%).

In rock fractions with the particle size of 1-13 mm, the highest ash content is in the dumps of the "Velykomostovska" mine (89.9\%), and the lowest is in the
"Vidrodzhennya" mine (80\%). The average ash content in dumps with rock fractions with the particle size of $1-13 \mathrm{~mm}$ is $86.45 \%$.

In rock fractions with the particle size of up to $1 \mathrm{~mm}$, the highest ash content is in the dumps of the "Zarichna" mine (80.9\%), and the lowest is in the "Chevonogradska" mine (63\%). The average ash content in dumps with rock fractions with the particle size of up to $1 \mathrm{~mm}$ is 72.25\% (Fig. 10).

Fig. 10. Ash content of dumps depending on the particle size distribution and density of the rock

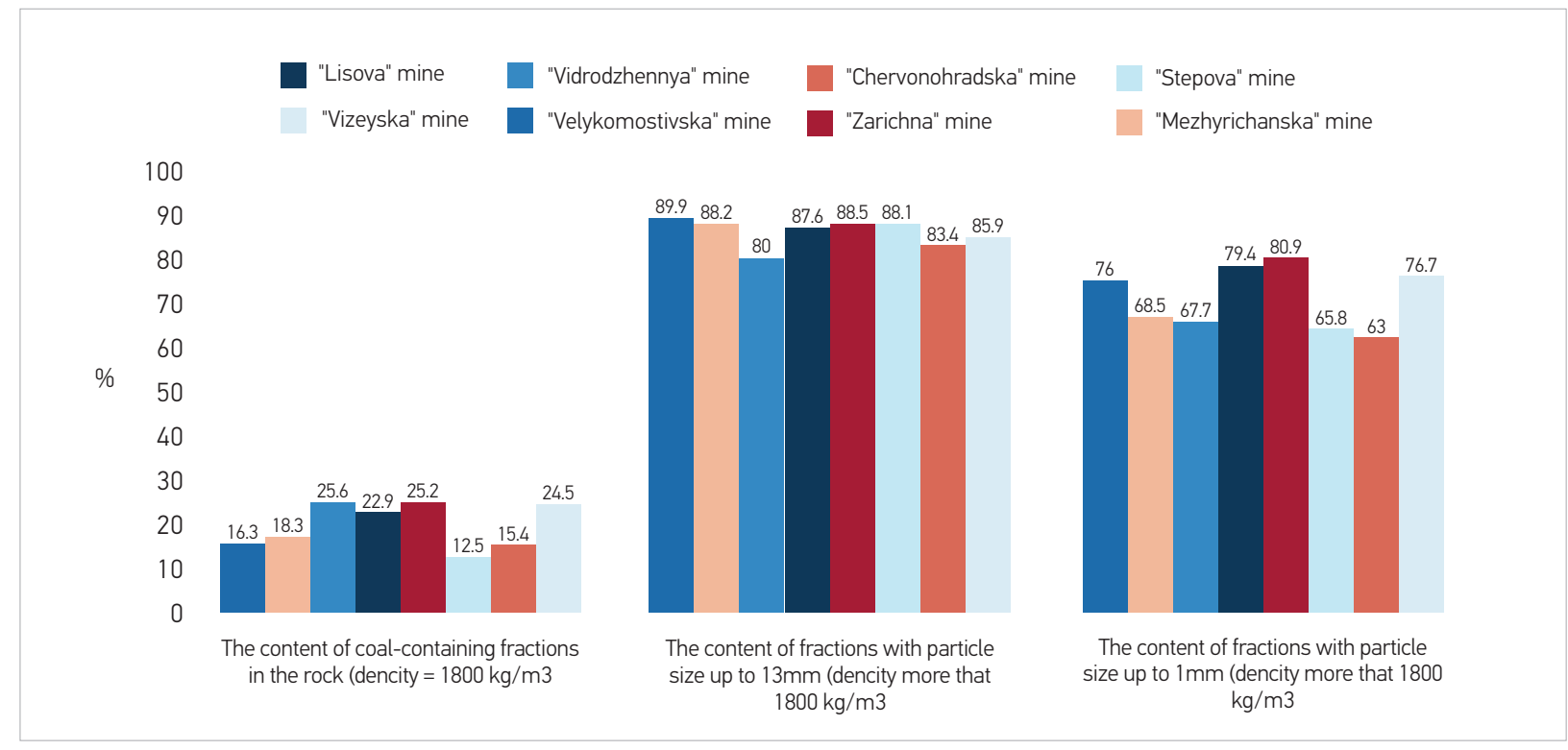

The robust relationship is observed between the ash content of coal-containing fractions of dumps and rock fractions of the size up to $1 \mathrm{~mm}$. The greater the ash content of coal-containing fractions in the dump, the higher the ash content in the rock fractions of the size of up to $1 \mathrm{~mm}$ (the correlation coefficient is high, positive $K=0.595433$ ). Such a correlation is disappointing, because when the ash content of coal-containing fractions of dumps decreases, the ash content of the smallest particles will decrease too, which in turn will lead to the liability of the rock to spontaneous combustion. Other relations between the ash content of different fractions were not found (Table 2).

The sulphur content in the investigated rocks is higher in the coal-containing particles. The highest sulphur content in coal-containing fractions is defined in the

Table 2. Correlation index of ash content in coal-containing and rock fractions in the dumps

\begin{tabular}{l|c|c|c}
\hline Ash content, \% & Coal-containing fractions, \% & Rock fractions $(\mathrm{d}=1-13 \mathrm{~mm}), \%$ & Rock fractions $(\mathrm{d} \leq 1 \mathrm{~mm}), \%$ \\
\hline Coal-containing fractions, \% & 1 & & \\
\hline Rock fractions $(\mathrm{d}=1-13 \mathrm{~mm}), \%$ & -0.33333 & 1 & 1 \\
\hline Rock fractions $(\mathrm{d} \leq 1 \mathrm{~mm}), \%$ & 0.595433 & 0.496322 & 1 \\
\hline
\end{tabular}


dumps of the "Lisova", "Stepova" and "Chervonogradska" mines (3\%, 2.8\%, and 2.5\%, respectively). The lowest sulphur content in coal-containing fractions was observed in dumps of the "Vidrodzhennya" and "Viseyska" mines (0.6\% and $0.8 \%)$. Average sulphur content in the coal-containing fractions of $1-13 \mathrm{~mm}$ make up $1.86 \%$. In rock fractions of 1-13 mm, the highest sulphur content is in the dumps of the "Chevonogradska" mine
(1.5\%), and the lowest is in the dumps of "Vidrodzhennya" mine $(0.2 \%)$. The average sulphur content in the rock fractions of $1-13 \mathrm{~mm}$ make up $0.75 \%$.

In rock fractions of up to $1 \mathrm{~mm}$, the highest ash content is in the dumps of the "Stepova" mine (2.2\%), and the lowest is in "Vidrodzhennya" mine dumps (0.8\%). The average ash content in the rock fractions up to $1 \mathrm{~mm}$ is 1.47\% (Fig. 11).

Fig. 11. Sulphur content in dumps depending on the particle size distribution and density of the rock

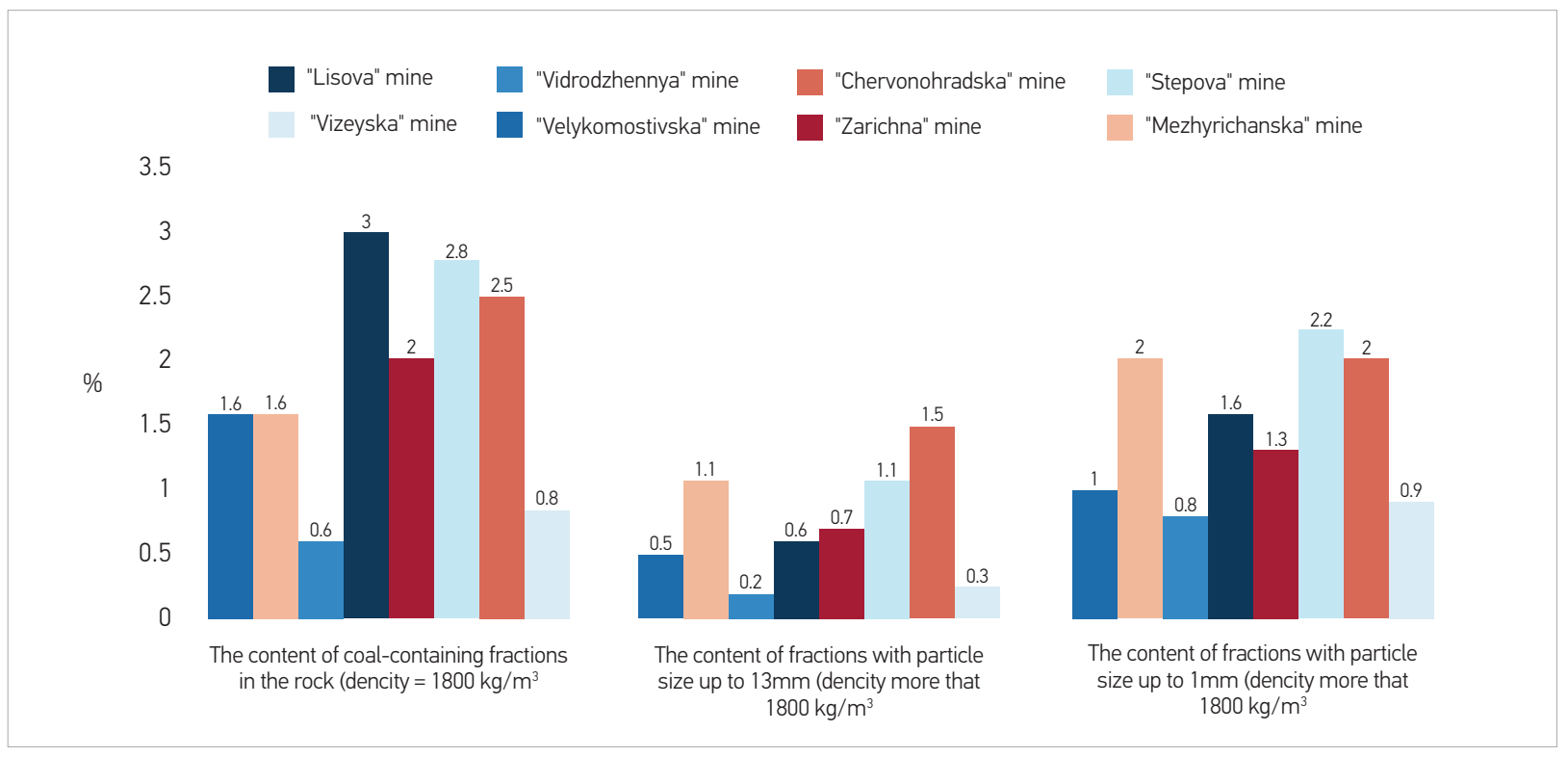

It should be noted that the correlation coefficients of sulphur content in coal-containing and rock fractions of different pore size distribution are high and positive, which proves their interrelation. If the sulphur concentration in the coal-containing rocks increases, then it will also increase in other types of fractions $(K=0.642078$ for particles of $1-13 \mathrm{~mm}$ and $\mathrm{K}=0.756475$ for particles up to $1 \mathrm{~mm}$ ). There is also a correlation of the sulphur content between the rock fractions of $1-13 \mathrm{~mm}$ and $1 \mathrm{~mm}$ $(K=0.908106)$ (Table 3).

Table 3. Correlation index of sulphur content in coal-containing and rock fractions in the dumps

\begin{tabular}{l|c|c|c}
\hline Sulphur content, \% & Coal-containing fractions, \% & Rock fractions $(\mathrm{d}=1-13 \mathrm{~mm}), \%$ & Rock fractions $(\mathrm{d} \leq 1 \mathrm{~mm}), \%$ \\
\hline Coal-containing fractions, \% & 1 & & \\
\hline Rock fractions $(\mathrm{d}=1-13 \mathrm{~mm}), \%$ & 0.642078 & 1 & 1 \\
\hline Rock fractions $(\mathrm{d} \leq 1 \mathrm{~mm}), \%$ & 0.756475 & 0.908106 & 1 \\
\hline
\end{tabular}

Thus, high concentrations of sulphur in coal-containing fractions of dumps migrate into other rock particles under the influence of natural factors and the rainfall. Such phenomena are extremely negative and cause the environmental pollution by hazardous substances. 


\section{Conclusions}

There are 55 mine dumps within the Lviv-Volyn coal basin. These devastated landscapes have a negative effect on the ecological state of the cities of Novovolynsk and Chervonograd and their suburbs. During research, operating (still dumped) and non-operating dumps (the dumping is stopped, although the burning actions are observed; in some sections the vegetation starts to grow) were explored.

The most dangerous landscape-transforming factors of mines dumps are ash and sulphur content in them. It has been established that the ash content of operating and non-operating dumps differs. The average content of ash in the rock of non-operating dumps is $79.95 \%$, and in particles with a diameter of up to 13 $\mathrm{mm}$, it is $78.22 \%$. For operating dumps, the ash content of coal-containing particles of the dumps rock is the lowest and is in the range of $12.5-25.6 \%$ (average $20.08 \%$ ). The average ash content in operating dumps with rock fractions of $1-13 \mathrm{~mm}$ is $86.45 \%$. The average ash content in operating dumps with rock fractions up to $1 \mathrm{~mm}$ is $72.25 \%$. Thus, the carbonaceous rock and rock with a particle size up to $1 \mathrm{~mm}$ are the most liable to spontaneous combustion.

With regard to the sulphur content in the rock of non-operating dumps with different particle size distribution, the elevated concentration occurs in fractions of the rock of up to $13 \mathrm{~mm}$ (average 1.06\%). In general, in the rock of non-operating dumps, the average sulphur

\section{References}

Afeni, T.B., \& Ibitolu, F. (2018). Assessment of environmental impact of gemstone mining in ljero-Ekiti, Nigeria. Mining of Mineral Deposits, 12(1), 1-11. Available at: https://doi.org/10.15407/ mining 12.01.001

Bashutska U. B. (2004) Antropohenno-pryrodni suktsesiyi roslynnosti devastovanykh landshaftiv Chervonohrads'koho hirnychopromyslovoho rehionu (Man-made-natural successions of vegetation of the devastated landscapes of the Chervonograd mining area): dys. ... kand. s.-h. nauk: spets. 06.03.01 "Lisovi kul'tury ta fitomelioratsiya". L'viv, 214 p. (In Ukrainian)

Bezrodna I. M. (2015) Posibnyk z laboratornoho praktykumu z content is $0.94 \%$. The content of sulphur in the rock of non-operating dumps is the highest for coal-containing particles. The average sulphur content in operating dumps with coal-containing fractions of $1-13 \mathrm{~mm}$ is $1.86 \%$. The highest sulphur content in coal-containing fractions was determined in the dumps of the mines "Lisova", "Stepova" and "Chervonogradska" (3\%, 2.8\%, and $2.5 \%$, respectively). The average of sulphur content in dumps with rock fractions of 1-13 $\mathrm{mm}$ makes up $0.75 \%$. The average ash content in dumps with rock fractions up to $1 \mathrm{~mm}$ is $1.47 \%$. Consequently, coal-containing fractions are the most technogenically dangerous from the viewpoint of the sulphur content, which interacts with other components and chemical elements and migrates to the environment. It should be noted that the sulphur content in the rock fractions of up to $1 \mathrm{~mm}$ that are washed away to the bottom of the dumps is also high.

In order to minimize the hazardous factors caused by dumps of coal mines, it is necessary to introduce environmental technologies on non-operating dumps. Such technologies include biological reclamation, including forest and agricultural reclamation and environmental monitoring on that area. For existing dumps, it is necessary to introduce modern technological processes, advanced transport and technical means, as well as control the storage technologies of mining waste.

kursu "Petrofizyka" (Textbook on laboratory practice of Petrophysics). K.: KNU im. T.Shevchenka, 58 (In Ukrainian).

Chetveryk, M., Bubnova, O. et al. (2018) Review of geomechanical problems of accumulation and reduction of mining industry wastes, and ways of their solution. Mining of Mineral Deposits, 12(4), 63-72. Available at: https://doi.org/10.15407/mining12.04.063 https://doi.org/10.15407/mining12.04.063

DSTU 4287:2004. Yakist gruntu. Vidbyrannya prob (State Standards of Ukraine) (In Ukrainian).

DSTU ISO 10381-8. Yakist' gruntu. Probovidbyrannya. Chastyna 8. Nastanovy z probovidbyrannya na vidvalakh (State Standards of Ukraine) (In Ukrainian). 
DSTU ISO 18512. Yakist' gruntu. Nastanovy z dovho ta korotkostrokovoho zberihannya zrazkiv gruntu (State Standards of Ukraine) (In Ukrainian).

DSTU ISO 11464:2007. Yakist' gruntu. Poperednye obroblyannya zrazkiv dlya fizyko-khimichnoho analizu (State Standards of Ukraine) (In Ukrainian).

DSTU 4362:2004. Yakist' gruntu. Pokaznyky rodyuchosti gruntiv (State Standards of Ukraine) (In Ukrainian).

Ekolohichnyy pasport m. Novovolyns'k vid 01.08.2018 (Ecological passport of Novovolynsk city from 01.08.2018) Available at:: https://voladm.gov.ua/article/ekologichniy-pasport-mnovovolinsk/ - Title from the monitor (in Ukrainian) https://doi. org/10.35652/IGJPS.2018.0108

Gonchar M. T. (1983). Lesnyye fitotsenozy: povysheniye produktivnosti i okhrana (na materialakh issledovaniy v lesakh ravninnoy chasti zapada Ukrainy) (Forest phytocenoses: increasing of productivity and protection (based on research materials in the forests of the flat part of western Ukraine)) L'vov : "Vishcha shkola", Izd-vo pri L'vov. un-te, 168 p. (in Russian)

Haydin A. M., Sobko B. YU. (2018) Hidroekolohiya pry hirnychykh robotakh (Hydroecology in mining works): monohraph - Dnipro: "Litohraf", 218 p. (in Ukrainian).

Karabyn, V., Shtain, B., Popovych, V. (2018) Thermal regimes of spontaneous firing coal washing waste sites. News of the National Academy of Sciences of the Republic of Kazakhstan, Series of Geology and Technical Sciences 3 (429), 64-74.

Klimkina I., Kharytonov M., Zhukov O. (2018) Trend Analysis of Water-Soluble Salts Vertical Migration in Technogenic Edaphotops of Reclaimed Mine Dumps in Western Donbass (Ukraine). Journal of Environmental Research, Engineering and Management Vol. 74, No. 2, 82-93. Available at: http://dx.doi. org/10.5755/j01.erem.74.2.19940 https://doi.org/10.5755/j01. erem.74.2.19940

Malyk YU. O., Holets N. YU. (2008) Analiz vplyvu polihonu tverdykh promyslovykh vidkhodiv Chervonohrads'koyi TSZF na dovkillya (Analysis of the impact of the solid industrial waste landfill of Chervonohrad CEP on the environment) Visnyk Natsional'noho universytetu "Lvivs'ka politekhnika", 609, 254-257 (In Ukrainian).

Myakina N. B., Arinushkina Ye. V. (1979) Metodicheskoye posobiye dlya chteniya rezul'tatov khimicheskikh analizov pochv (Methodics for studying the results of chemical analyzes of soil) Izdatelstvo Moskovskogo universiteta, 62. (in Russian).Mykhaylov V. A., Kurylo M. V. et al. (2009) Horyuchi korysni kopalyny Ukrayiny (Fossil fuels of Ukraine) - Kyiv: KNT, 376 p. (in Ukrainian).

Pavlichenko A.V., Kolesnik V.Ye., Buchavy Yu.V. (2016) Determination of dynamic parameters of dust emission from a coal mine fang. Naukovyy visnyk Natsional'noho hirnychoho universytetu 2, 81-87.

Popovych, V., Kuzmenko, O. et al. (2018) Influence of manmade edaphotopes of the spoil heap on biota. E3S Web of Conferences. 60: 00010. Available at: https://doi.org/10.1051/ e3sconf/20186000010

Tulaydan, Y., Malovanyy, M. et al. (2017) Treatment of highstrength wastewater from ammonium and phosphate ions with the obtaining of struvite. Chemistry \& Chemical Technology. Vol.11, 4, 463-468. Available at: https://doi.org/10.23939/ chcht11.04.463 https://doi.org/10.23939/chcht11.04.463

Yadav, A. K. (2015). Elemental composition and source apportionment of suspended particulate matters and health risk assessment in mining and nonmining areas of Odisha, India. Journal of Hazardous, Toxic and Radioactive Waste, 19(3), 4014037. Available at: https://ascelibrary.org/doi/abs/10.1061/(ASCE) HZ.2153-5515.0000248

Yadav, A. K., \& Jamal, A. (2016) A review on the present scenario of air quality associated with Indian mining operations. Environmental Quality Management, 25(3), 99-105. Available at: https://onlinelibrary.wiley.com/doi/abs/10.1002/tqem.21459

Yadav A.K, Jamal A. (2018) Suspended particulate matter and their management system surrounding opencast coal mines. Environmental Quality Management, 1-6. Available at: https:// doi.org/10.1002/tqem.21592 